\title{
PENDAPATAN USAHATANI KACANG TANAH DI DESA KANONANG II KECAMATAN KAWANGKOAN
}

\author{
Grace A.J. Rumagit \\ Oktavianus Porajouw \\ Rizky Mirah
}

\begin{abstract}
The aim of this study is to determine the income of peanut's farm in The Second Kanonang Village at Kawangkoan District. Primary and seconndary data are used and analyzed by making use of descriptive analysis and $\mathrm{R} / \mathrm{C}$ ratio. Results of this study indicates that: (1) the average revenue of peanut farmers is Rp6.053.800 and the average cost of Rp 3.182.577 so that the average income received by farmers is $\mathrm{Rp} 2.871 .223$ per one time of planting, and (2) the $\mathrm{R} / \mathrm{C}$ ratio (1.90) is greater than one, showed that the average income received by farmers is relatively favorable.
\end{abstract}

Keywords: Income, Peanut, Return cost ratio

\section{PENDAHULUAN}

\section{Latar Belakang}

Pembangunan nasional di bidang pertanian bertujuan untuk meningkatkan kesejahteraan dan taraf hidup petani. Oleh sebab itu sasaran dari pembangunan pertanian antara lain untuk meningkatkan pendapatan petani. Mosher (1991) mengemukakan bahwa usaha peningkatan produksi dan pendapatan petani tergantung pada perilaku petani dalam berusahatani. Berhasil tidaknya suatu usahatani dalam mencapai tujuannya tergantung pada bagaimana cara pengelolaan cabang usahatani yang diusahakannya dimana petani berperan gandan baik sebagai manager maupun sebagai pelaksana.

Dalam pengelolaan usahataninya, petani mengupayakan agar hal yang diperoleh secara ekonomis menguntungkan, dimana biaya yang dikeluarkan dapat menghasilkan produksi yang maksimal. Sehingga pada akhirnya pendapatan petani akan meningkat, dan dengan meningkatkannya pendapatan maka secara otomatis tingkat kesejahtraan petani tersebut akan meningkat pula. Salah satu komoditi pertanian yang dapat membantu meningkatkan pendapatan dan kesejahteraan petani adalah kacang tanah (Arachis Hypogaea, L.). Tanaman kacang tanah adalah tanaman palawija. Di Kabupaten Minahasa Kecamatan Kawangkoan merupakan sentra produksi tanaman kacang tanah, dengan luas areal dan produksi yang lebih tinggi dari kecamatan-kecamatan lainnya. Di Kecamatan Kawangkoan, desa Kanonang II adalah desa yang menghasilkan tanaman kacang tanah terbesar, dapat di lihat pada Tabel 1.

Tabel 1. Luas Areal dan Produksi Kacang Tanah di Kecamatan Kawangkoan Tahun 2009

\begin{tabular}{|l|l|c|c|}
\hline No. & \multicolumn{1}{|c|}{ Desa } & $\begin{array}{c}\text { Luas } \\
\text { lahan } \\
\text { (ha) }\end{array}$ & $\begin{array}{c}\text { Produk- } \\
\text { tivitas } \\
\text { (ton/ha) }\end{array}$ \\
\hline 1. & Tondegesan & 63 & 1,6 \\
\hline 2. & Uner & 54 & 1,4 \\
\hline 3. & Kinali & 36 & 1,3 \\
\hline 4. & Talikuran & 32 & 1,3 \\
\hline 5. & Sendangan & 24 & 1,2 \\
\hline 6. & Kiawa I & 18 & 1,1 \\
\hline 7. & Kiawa II & 18 & 1,2 \\
\hline 8. & Kanonang I & 209 & 1,7 \\
\hline 9. & Kanonang II & 226 & 1,7 \\
\hline 10. & Kayuuwi & 135 & 1,5 \\
\hline 11. & Tombasian Atas & 130 & 1,5 \\
\hline 12. & Tombasian Bawah & 35 & 1,2 \\
\hline 13. & Ranolambot & 40 & 1,4 \\
\hline
\end{tabular}

Sumber: Balai Penyuluhan Pertanian Kecamatan Kawangkoan 
Tanaman kacang tanah memiliki peranan yang sangat penting bagi petani yang mengusahakannya di Desa Kanonang II. Usahatani kacang tanah di desa ini telah dilakukan sejak lama dan turun-temurun tujuannya adalah sebagai sumber pendapatan utama bagi petani di desa tersebut. Hal ini dikarenakan tanaman kacang tanah mampu memberilkan pendapatan yang relatif lebih tinggi dibandingkan dengan pendapatan yang diperoleh dari cabang usahatani yang lainnya, karena harga jual kacang tanah mentah maupun kering yang diterima petani rata-rata relatif tinggi.

Petani kacang tanah di Desa Kanonang II sebagian besar menjual kacang tanah dalam keadaan mentah dari pada di jual dalam keadaan kering, walaupun demikian para petani sudah merasa cukup dalam pendapatan yang diterima. Namun, perhitungan pendapatan dari usahatani ini jarang dilakukan oleh petani sehingga tidak ada informasi sampai seberapa besar pendapatan yang di perolehnya dari usahatani kacang tanah.

Untuk itu penelitian ini perlu untuk di laksanakan, sehingga dapat di ketahui dengan pasti pendapatan yang di peroleh petani dari usahatani kacang tanah.

\section{Perumusan Masalah}

Berdasarkan latar belakang yang dikemukakan di atas, maka yang menjadi permasalahan dalam penelitian ini adalah seberapa besar pendapatan usahatani kacang tanah di Desa Kanonang II Kecamatan Kawangkoan.

\section{Tujuan dan Manfaat Penelitian}

Penelitian ini bertujuan untuk mengetahui pendapatan usahatani kacang tanah di Desa Kanonang II Kecamaan Kawangkoan. Manfaat dari penelitian ini adalah sebagai bahan informasi bagi petani agar dapat mengembangkan pendapatan usahatani kacang tanah sehingga menjadi lebih baik lagi.

\section{TINJAUAN PUSTAKA}

\section{Deskripsi Umum Tanaman Kacang Tanah}

Tanaman kacang tanah (Arachis Hypogae, L.), yang sudah terbasar luas dan ditanam di Indonesia ini sebetulnya bukanlah tanaman asli, melainkan tanaman yang berasal dari benua Amerika, tepatnya di daerah Brazilia (Amerika Selatan) pada waktu itu di daerah tersebut sudah terdapat berbagai jenis spesies lebih dari 6-17 Arachis. Mulamula kacang tanah ini di bawah dan disebarkan ke benua Eropa kemudian menyebar ke bensua Asia. Tanaman kacang tanah ini diperkirakan masuk ke Indonesia antara tahun 1521 - 1529. Namun ada sementara pendapat yang menggatakan bahwa tanaman ini masuk ke Indonesia setelah tahun 1557.

Kacang tanah adalah tanaman palawija, yang tergolong dalam family Leguminoceae sub family Papilionoideae, genus Arachis dan Hypogaea. Tanaman kacang tanah membentuk polong (buah) dalam tanah. Pertumbuhan kacang tanah, secara garis besar dapat dibedakan menjadi dua macam tipe yaitu : tipe tegak (Bunch type, Erect type, Fastigiate) dan tipe menjalar (Runner type, Prostrate type Procumbent).

\section{Usahatani}

Berusahatani sebagai suatu kegiatan untuk memperoleh produksi dilahan pertanian, pada akhirnya akan dinilai dari biaya yang dikeluarkan dan penerimaan yang diperoleh. Selisih keduanya merupakan pendapatan dari kegiatannya. Efferson dalam Ratag (1978) mengemukakan bahwa suatu usahatani yang baik adalah usaha menempatkan faktor-faktor produksi pada suatu kombinasi dan cara yang baik, sehingga diperoleh keuntungan yang besar dalam suatu jangka waktu tertentu.

\section{Biaya}

Biaya dalam kegiatan usahatani oleh petani ditujukan untuk menghasilkan pendapatan yang tinggi bagi usahatani yang dikerjakan. Dengan mengeluarkan biaya maka petani mengharapkan pendapatan yang setinggi-tingginya melalui tingkat produksi yang tinggi.

Biaya produksi dapat didefinisikan sebagai semua pengeluaran yang dilakuakan oleh perusahan untuk memperoleh faktor-faktor produksi bahan bahan mentah yang akan di gunakan untuk menciptakan barang-barang yang di produksi peusahan tersebut (Sukirno 2002). 


\section{Penerimaan Dan Pengeluaran}

Penerimaan atau pandapatan kotor dapat diartikan sebagai nilai produk total dalam jangka waktu tertentu baik yang dipasarkan maupun tidak. Penerimaan usahatani terdiri dari hasil penjualan produksi pertanian, produksi yang dikonsumsi dan kenaikan nilai invertaris. Penerimaan usahatani adalah perkalian antara produksi yang diperoleh dengan harga jualnya. Menurut Hernanto (1993), penerimaan usahatani yaitu penerimaan dari sumber-sumber usahatani dan keluarga.

Pengeluaran usahatani terdiri dari pengeluaran untuk biaya tetap dan biaya variable. Biaya tetap meliputi : pajak, penyusutan alat-alat produksi, bunga pinjaman sewa tanah dan lain-lain. Biaya tetap ini tidak dipengaruhi besarnya produksi. Biaya variabel meliputi : biaya tenaga kerja, dan lain-lain. Biaya variabel ini sifatnya berubah sesuai dengan besarnya produksi.

\section{Pendapatan}

Pendapatan diartikan sebagai selisih antara besarnya penerimaan dan biaya yang dikeluarkan. Selain itu pendapatan dapat digambarkan sebagai balas jasa dan kerja sama faktor-faktor produksi yang disediakan oleh petani sebagai penggerak, pengelolah, pekerja dan sebagai pemilik modal. Menurut Mubyarto (1991) pendapatan merupakan hasil pengurangan antara hasil penjualan dengan semua biaya yang dikeluarkan mulai dari masa tanam sampai produk tersebut berada ditangan konsumen akhir.

\section{METODE PENELITIAN}

\section{Metode Pengumpulan Data}

Penelitian ini dilaksanakan di Desa Kanonang II Kecamatan Kawangkoan, dengan data yang digunakan berupa data primer dan data sekunder. Dimana data primer diperoleh melalui wawancara langsung dengan petani responden berdasarkan daftar pertanyaan sedangkan data sekunder diperoleh dari pihak-pihak atau instansi yang terkait.

\section{Metode Pengambilan Sampel}

Pengambilan sampel dilakukan dengan cara simple random sampling, yaitu petani yang melakukan usahatani kacang tanah sebagai tanaman pokok dengan jumlah responden yang diambil sebanyak 30 petani.

\section{Konsep Pengukuran Variabel}

1. Karakteristik petanu: umur, tingkat pendidikan dan jumlah anggota keluarga.

2. Luas lahan yang digunakan petani dalam kegiatan usahatani (ha).

3. Jumlah produksi yaitu jumlah produksi kacang tanah dalam satu kali panen $(\mathrm{kg})$.

4. Harga yaitu harga jual di tingkat petani $(\mathrm{Rp} / \mathrm{kg})$.

5. Biaya produksi yaitu biaya yang dikeluarkan selama proses produksi berlangsung terdiri dari:

a. Biaya tetap:

- Pajak (Rp/tahun)

- Sewa lahan (Rp)

- Penyusutan alat (Rp)

b. Biaya variabal:

- Benih (Rp/kg)

- Pestisida (Rp/btl)

- Tenaga kerja (Rp/HOK)

- Sewa pengangkutan

- Pasca panen

6. Penerimaan yaitu total jumlah produksi kacang tanah yang diperoleh per satu kali proses produksi dikali dengan harga (Rp).

7. Pendapatan usahatani kacang tanah yaitu selisih antara total penerimaan dengan total pengeluaran $(\mathrm{Rp})$.

\section{Metode Analisis Data}

Data yang diperoleh dalam penelitian ini dianalisis secara deskriptif, dimana data yang dikumpulkan disajikan dalam bentuk tabel dan dilanjutkan dengan perhitungan analisis pendapatan yaitu:

Dimana:

$$
\mathrm{Pd}=\mathrm{TR}-\mathrm{TC}
$$

$\mathrm{Pd}=$ Pendapatan Usahatani Kacang Tanah

$\mathrm{TR}=$ Total Revenue (Total penerimaan)

$\mathrm{TC}=$ Total Cost (Total biaya)

Untuk mengetahui efisien usahatani kacang tanah di Desa Kanonang II, maka digunakan rumus Analisis Return Cost Ratio:

$$
\mathrm{a}=\mathrm{R} \div \mathrm{C}
$$


Dimana:

$$
\begin{array}{ll}
\mathrm{a} & =\text { Return Cost Ratio } \\
\mathrm{R} & =\text { Return (Penerimaan) } \\
\mathrm{C} & =\text { Cost (Biaya) }
\end{array}
$$

\section{Waktu Penelitian Dan Tempat}

Penelitian ini berlangsung selama tiga bulan sejak bulan Agustus sampai Oktober 2010, sejak persiapan hingga penyusunan laporan hasil penelitian. Tempat penelitian dilaksanakan di Desa Kanonang II Kecamatan Kawangkoan.

\section{HASIL DAN PEMBAHASAN}

\section{Umur petani \\ Karakteristik Petani Responden}

Umur sangat mempengaruhi kemampuan fisik seseorang dalam menjalankan aktivitasnya. Komposisi tingkat umur petani responden di Desa Kanonang II Kecamatan Kawangkoan dapat dilihat pada Tabel 2.

Tabel 2. Jumlah Responden Petani Menurut Tingkat Umur

\begin{tabular}{|c|c|c|}
\hline $\begin{array}{c}\text { Tingkat } \\
\text { Umur } \\
\text { (tahun) }\end{array}$ & $\begin{array}{c}\text { Jumlah Petani } \\
\text { (orang) }\end{array}$ & $\begin{array}{c}\text { Persentase } \\
(\%)\end{array}$ \\
\hline $30-40$ & 7 & 23 \\
$41-50$ & 13 & 43 \\
$\geq 51$ & 10 & 34 \\
\hline Total & 30 & 100 \\
\hline
\end{tabular}

Sumber: Diolah dari data primer, 2010

\section{Tingkat Pendidikan}

Tingkat pendidikan merupakan faktor yang sangat penting yang menentukan tingkat kecakapan petani dalam menjalankan tugas serta fungsinya baik sebagai manajer maupun juru tani. Semakin tinggi tinggkat pendidikan seorang petani maka semakin mudah menerima masukan dan saran dalam mengelolah usahanya. Adapun tingkat pendidikan petani responden dapat dilihat pada Tabel 3.
Tabel 3. Jumlah dan Persentase Petani Responden Menurut Tingkat Pendidikan

\begin{tabular}{|c|c|c|}
\hline $\begin{array}{c}\text { Tingkat Pen- } \\
\text { didikan }\end{array}$ & $\begin{array}{c}\text { Jumlah } \\
\text { (Orang) }\end{array}$ & $\begin{array}{c}\text { Persentase } \\
(\%)\end{array}$ \\
\hline SD & 7 & 23 \\
SMP & 15 & 50 \\
SMA & 8 & 27 \\
\hline Total & 30 & 100 \\
\hline
\end{tabular}

Sumber: Diolah dari data primer, 2010

\section{Jumlah Anggota Keluarga}

Jumlah anggota keluarga petani kacang tanh di Desa Kanonang II dari 30 reponden, semuanya sudah berkeluarga. Pada umumnya jumlah anggota keluarga terdiri dari responden itu sendiri, istri, anak-anak. Jumlah anggota keluarga responden dapat dilihat pada Tabel 4.

Tabel 4. Jumlah Anggota Keluarga Petani Kacang Tanah

\begin{tabular}{|c|c|c|}
\hline $\begin{array}{c}\text { Jumlah Anggota } \\
\text { Keluarga }\end{array}$ & $\begin{array}{c}\text { Jumlah Pe- } \\
\text { tani }\end{array}$ & $\begin{array}{c}\text { Persentase } \\
(\%)\end{array}$ \\
\hline$\leq 2$ & 4 & 14 \\
$3-5$ & 20 & 66 \\
$\geq 6$ & 6 & 20 \\
\hline Total & 30 & 100 \\
\hline
\end{tabular}

Sumber: Diolah dari data primer, 2010

\section{Karakteristik Usahatani Kacang Tanah Luas Lahan}

Dalam melakukan suatu usaha di bidang pertanian, lahan merupakan faktor yang penting untuk menghasilkan suatu produksi. Keadaan lahan serta luas lahan akan mempengaruhi produksi dan penggunaan tenaga kerja dari suatu usahatani.

Petani kacang tanah di Desa Kanonang II Kecamatan Kawangkoan memiliki kisaran luas lahan antara $0,25-2$ hektar dengan luas rata-rata 1,3 hektar. Luas lahan pertanian dapat dilihat pada Tabel 5. 
Tabel 5. Luas Lahan Pertanian di Desa Kanonang II

\begin{tabular}{|c|c|c|}
\hline $\begin{array}{c}\text { Luas Lahan } \\
(\mathrm{Ha})\end{array}$ & $\begin{array}{c}\text { Jumlah Res- } \\
\text { ponden } \\
\text { (Orang) }\end{array}$ & $\begin{array}{c}\text { Persentase } \\
\mathbf{( \% )}\end{array}$ \\
\hline $0,25-0,50$ & 7 & 23 \\
$0,51-1$ & 8 & 27 \\
$>1$ & 15 & 50 \\
\hline Total & 30 & 100 \\
\hline
\end{tabular}

Sumber: Diolah dari data primer, 2010

\section{Produksi}

Pola penanaman kacang tanah di Desa Kanonang II pada umumnya tidak mengikuti jarak tanam yang ditentukan untuk tanaman kacang tanah, karena di pengaruhi oleh keadaan topografi wilayah yang ada sebagian merupakan tanah berbukit. Hal ini pada akhirnya mempengaruhi jumlah produksi yang dihasilkan tidak maksimal.Tanaman kacang tanah berbuah satu kali dalam $100-120$ hari ( $3-4$ bulan) . cara pemanenannya dilakukan jika buah kacang tanah daunnya mulai menguning dan sebagian mulai berguguran.Berdasarkan hasil penelitian $100 \%$ petani responden memproduksi buah kacang tanah bervariasi antara $210-1470$ liter per satu kali masa tanam dengan produksi rata-rata 776 liter per petani.

\section{Harga}

Harga julal merupakan salah satu variabel penting yang menentukan besarnya penerimaan dari usahatani kacang tanah. Harga yang digunakan dalam penelitan ini adalah harga pada bulan juni sampai juli 2010. Harga kacang tanah dapat dilihat pada Tabel 6 berikut:

Tabel 6. Harga Jual Produk Kacang Tanah

\begin{tabular}{|c|c|c|}
\hline $\begin{array}{c}\text { Harga } \\
(\mathrm{Rp})\end{array}$ & $\begin{array}{c}\text { Jumlah Res- } \\
\text { ponden } \\
\text { (orang) }\end{array}$ & $\begin{array}{c}\text { Persentase } \\
(\%)\end{array}$ \\
\hline 7700 & 20 & 66,6 \\
8000 & 10 & 33,3 \\
\hline Jumlah & 30 & 100 \\
\hline
\end{tabular}

Sumber: Diolah dari data primer,2010

\section{Penerimaan}

Penerimaan usahatani merupakan perkalian antara jumlah produksi buah kacang tanah dengan harga jual ditingkat petani. Oleh karena itu besarnya penerimaan petani kacang tanah tergantung pada jumlah produksi kacang tanah dan harga yang berlaku ditingkat petani. Hasil penelitian ini menunjukan bahwa besarnya penerimaan usahatani kacang tanah di Desa Kanonang II Kecamatan Kawangkoan berkisar pada Rp1.617.000 Rp11.760.000 dengan rata-rata penerimaan adalah Rp6.053.800

\section{Biaya Produksi}

Biaya produksi adalah seluruh pengeluaran untuk membiayai proses produksi dalam usahatani. Biaya yang dihitung dalam penelitian ini adalah biaya yang dikeluarkan selama satu kali produksi yang digolongkan ke dalam biaya tetap dan biaya variabel.

Biaya tetap meliputi pajak dan biaya penyusutan peralatan pertanian yang terdiri dari : Cangkul, Parang, Sprayer dan Bajak. Sedangkan biaya variabel meliputi sewa lahan, biaya pengadaan benih, biaya transportasi dan biaya tenaga kerja. Komponen-komponen biaya yang dikeluarkan petani kacang tanah di Desa Kanonang II dapat dilihat pada Tabel 7

\section{Pendapatan Usahatani}

Berusahatani sebagai suatu kegiatan untuk memperoleh produksi dilapangan pertanian pada akhirnya akan dinilai dari biaya yang dikeluarkan dan penerimaan yang diperoleh, selisih keduanya merupakan pendapatan usahatani. Pendapatan dalam pengertian teknisnya dikatakan sebagai selisih antara penerimaan dengan pengeluaran dalam produksi usahatani yang dihitung dalam suatu jangka wakti tertentu. 
Tabel 7. Komponen Biaya Produksi Usahatani Kacang Tanah di Desa Kanonang

\begin{tabular}{|c|c|c|c|}
\hline No. & Jenis Biaya & Rata-rata & $\begin{array}{c}\text { Persen- } \\
\text { tase } \\
(\%)\end{array}$ \\
\hline 1. & $\begin{array}{l}\text { Biaya Tetap } \\
\text { - Pajak } \\
\text { - Penyusutan Perala- } \\
\text { tan } \\
\text { - Cangkul } \\
\text { - Parang } \\
\text { - Bajak } \\
\text { - Sprayer }\end{array}$ & $\begin{array}{c}995 \\
1.136 \\
6.694 \\
404\end{array}$ & $\begin{array}{l}0,03 \\
0,04 \\
0,19 \\
0,01\end{array}$ \\
\hline & Biaya Tetap Total & 29.304 & 0,85 \\
\hline 2. & $\begin{array}{l}\text { Biaya Variabel } \\
\text { - Sewa Lahan } \\
\text { - Pengadaan Benih } \\
\text { - Biaya Transportasi } \\
\text { - Biaya Tenaga kerja } \\
\text { - Pembersihan } \\
\text { - Membajak } \\
\text { - Pembedengan } \\
\text { - Penanaman } \\
\text { - Panen } \\
\text { - Biaya Pemeliharaan } \\
\text { - Pemupukan } \\
\text { - Penyemprotan }\end{array}$ & $\begin{array}{c}250.000 \\
870.833 \\
145.000 \\
\\
115.333 \\
58.333 \\
85.333 \\
209.000 \\
1.562 .000 \\
\\
38.750 \\
93.000\end{array}$ & $\begin{array}{c}7,23 \\
25,19 \\
4,20 \\
\\
3,34 \\
1,69 \\
2,47 \\
6,04 \\
45,18 \\
\\
1,12 \\
2,69\end{array}$ \\
\hline & Biaya Variabel Tetap & 3.427 .582 & 99,15 \\
\hline & Biaya Total & 3.456 .886 & 100 \\
\hline
\end{tabular}

Sumber: Diolah dari data primer, 2010

Dalam penelitian ini pendapatan yang dihitung adalah selama satu kali masa tanam. Pendapatan usahatani dapat di lihat pada Tabel 8.

Tabel 8. Pendapatan Usahatani Kacang Tanah di Desa Kanonang

\begin{tabular}{|c|l|c|}
\hline No. & \multicolumn{1}{|c|}{ Uraian } & $\begin{array}{c}\text { Rata-Rata } \\
\text { per Petani }\end{array}$ \\
\hline 1. & Penerimaan (Rp) & 6.053 .800 \\
2. & Biaya (Rp) & 3.182577 \\
3. & Pendapatan (Rp) & 2.871 .223 \\
4. & Pendapatan per hektar (Rp) & 2.676 .625 \\
\hline
\end{tabular}

Sumber: Diolah dari data primer, 2010

Dari Tabel 8 dapat dilihat bahwa dengan penerimaan sebesar Rp6.053.800 dan biaya rata-rata Rp3.182.577 maka pendapatan rata-rata yang di- terima petani adalah Rp2.871.223 sedangkan dilihat dari rata-rata pendapatan per hektar adalah sebesar Rp2.676.625

\section{Return cost ratio}

Tingkat keuntungan ekonomi dapat diketahui dengan menggunakan analisis Return Cost Ratio ( $\mathrm{R} / \mathrm{C}$ ratio). Analisis $\mathrm{R} / \mathrm{C}$ adalah perbandingan antara penerimaan dan biaya.

Analisis R/C untuk usahatani kacang tanah di Desa Kanonang II:

$$
\begin{aligned}
\mathrm{a} & =\mathrm{R} / \mathrm{C} \\
& =\mathrm{Rp} 181,614,000 / \mathrm{Rp} 95,477,304 \\
& =1,90
\end{aligned}
$$

Dari analisis $\mathrm{R} / \mathrm{C}$ untuk usahatani kacang tanah di Desa Kanonang II Kecamatan Kawangkoan didapat nilai 1,90

\section{Kesimpulan}

Hasil penelitian menunjukan bahwa penerimaan rata-rata petani kacang tanah di Desa Kanonang II adalah sebesar Rp6.053.800 dan biaya rata-rata sebesar Rp3.182.577 sehingga pendapatan rata-rata yang diterima petani adalah $\mathrm{Rp} 2.871 .223$ per satu kali masa tanam.

Dan dilihat dari nilai $\mathrm{R} / \mathrm{C}$ yang lebih besar dari 1 yaitu 1,90 dan rata-rata pendapatan yang diterima petani dalam satu kali panen relatif menguntungkan

\section{Saran}

Untuk lebih meningkatkan pendapatan petani kacang tanah di Desa Kanonang II Kecamatan Kawangkoan maka petani harus menyediakan lahan yang luas serta dapat menciptakan benih/bibit yang ungul sendiri tanpa harus di beli dari petani lain. Selain itu petani harus mempelajari teknologi pertanian melalui penggunaan bibit.

\section{DAFTAR PUSTAKA}

Anonimous, 2010. Kecamatan Kawangkoan Dalam Angka.

AAk, 1995. Kacang Tanah. Kanisius, Yogyakarta

Bambang, S., 1992. Biaya Produksi. Rineke Cipta 
Balai Penyuluhan Pertanian Kecamatan Kawangkoan, 2009. Penjabaran Tanam Intesifikasi. Laporan Tahunan.

Hadisaputra, 1973. Biaya dan Pendapatan Di Dalam Usahatani. Departamen Ekonomi Pertanian UGM, Yogyakarta

Hernanto, 1993. Ilmu Usahatani. Swadaya, Jakarta

Mubyarto, 1991. Pengantar Ekanomi Pertanian. LP3ES, Jakarta.

Ratag, J.G.A., 1982. Sendi-Sendi Dasar Ilmu Usahatani. Fakultas Pertanian UNSRAT, Manado
Ratag, S., 2004. Pendapatan Usahatani Vanili di Desa Pinamorongan Kec. Tareran. Jurusan Sosial Ekonomi Fakultas Pertanian UNSRAT. Manado

Sondakh, R.M., 2010. Pendapatan Usahatani Campuran Di Desa Kumu Kecamatan Tombariri Kabupaten Minahasa. Jurusan Sosial Ekonomi Fakultas Pertanian UNSRAT. Manado

Soeharno, 2006., Teori Ekonomi Mikro. Penerbit ANDI. Yogyakarta

Soehardjo dan Patong, 1973. Sendi-Sendi Pokok Usahatani. Fakultas Pertanian UNSRAT, Manado

Soekartawi, 1995. Analisis Usahatani. Universitas Indonesia, Jakarta 